Article

\title{
Factors Influencing Levels of CSR Disclosure by Forestry Companies in China
}

\author{
Feifei Lu ${ }^{1,2}$, Robert Kozak ${ }^{2}$, Anne Toppinen ${ }^{3}$ (D) , Dalia D'Amato ${ }^{3,4}$ and Zuomin Wen ${ }^{1, *}$ \\ 1 College of Economics and Management, Nanjing Forestry University, No. 159 Longpan Road, \\ Xuanwu District, Nanjing 210037, China; f.f.lu@hotmail.com \\ 2 Faculty of Forestry, University of British Columbia, 2424 West Mall, Vancouver, BC V6T 1Z4, Canada; \\ rob.kozak@ubc.ca \\ 3 Department of Forest Sciences, University of Helsinki, Latokartanonkaari 7, 00014 Helsinki, Finland; \\ anne.toppinen@helsinki.fi (A.T.); dalia.damato@helsinki.fi (D.D.) \\ 4 Department of Management Studies, Aalto University, Lapuankatu 2, 00076 Helsinki, Finland \\ * Correspondence: zuominwen@hotmail.com
}

Received: 7 August 2017; Accepted: 21 September 2017; Published: 4 October 2017

\begin{abstract}
With the international community's increasing concern for social and environmental problems, the fulfilment and disclosure of corporate social responsibility (CSR) has been advocated and promoted across the world. Forestry companies, which are particularly sensitive to environmental and social issues, are increasingly developing and improving their levels of CSR disclosure. However, information on emerging country contexts is still lacking. To fill this gap, this study focuses on Chinese forestry companies' CSR disclosure and introduces new disclosure indices through content analysis of annual reports by listed companies between 2011 and 2015. It then builds a correlation analysis of the factors influencing these companies' disclosure indices in order to gain a better understanding of the current situation for CSR implementation by forestry companies in emerging economies like China. Although context-specific, our findings can provide a reference for researchers and policy makers, and promote sustainable development via improved CSR disclosure by forestry companies, especially in developing regions.
\end{abstract}

Keywords: China; CSR disclosure; influencing factors; forestry companies; sustainable development

\section{Introduction}

In recent years, with the international community's increasing concern for social and environmental problems, a wide range of stakeholders and issues apart from meeting core shareholder interests, has become increasingly influential in determining the long-term viability of businesses [1,2]. Consequently, the improvement and disclosure of corporate social responsibility (CSR) has been advocated and promoted across the world [3,4]. International institutions, such as the Global Reporting Initiative (GRI) and ISO26000, have encouraged enterprises to undertake their due share of economic, environmental, and social responsibilities (GRI, in particular, is among the most common guidelines for CSR disclosure globally [5,6]. In 1999, the United Nations Environment Program (UNEP) promoted the GRI initiative and, in 2002, officially recognized it. In 2002, 2006, and 2013, the GRI released the revised versions of Sustainability Reporting Guidelines, respectively, G2, G3, and G4). This has exerted a positive influence on CSR disclosure on a global scale [7]. CSR disclosure is particularly salient in the forest sector, which faces the formidable challenge of reconciling growing fibre demand, while guaranteeing the sustainable management of forest ecosystem services, including water resources, climate control, and cultural values [1,8-12]. CSR in the forest sector has been driven largely by legitimacy pressures [13-18]. In the context of emerging economies like China, 
legitimacy challenges [19] are also coupled with rapidly increasing sustainability requirements and standards [20,21].

Several studies have investigated CSR disclosure in the forest sector at regional or global scales, especially in reference to the GRI framework [22-26]. Current research, however, mainly focuses on CSR disclosure in the context of developed economies [27,28]. Research on CSR disclosure by forestry companies in emerging economies is still scarce, despite these regions' increasing role in the global trade of forest products [29-33].

This study aims at: (1) describing the status of CSR levels in listed Chinese forestry firms during the period 2011-2015; and (2) identifying the influences of firm characteristics on CSR disclosure levels. Potential contributions of our study include: (1) applying a CSR disclosure framework to forestry companies in China and, by doing so, extending the understanding of potential associations between the characteristics of Chinese forestry companies and CSR disclosure levels; (2) expanding and updating previous research conducted in China on the topic, while gaining a broader understanding of CSR with time series data; and (3) as the largest emerging economy, providing a reference point on CSR activities in other emerging economies for researchers, practitioners, and managers. Ultimately, it is hoped that this research will serve to promote sustainable development and the reliable disclosure of CSR activities by forestry companies in China.

\section{Background}

China is a particularly interesting example for analyzing the progress of CSR disclosure. Since the turn of the century, China has been a strong advocate of sustainable development. With China's entry into the World Trade Organization in 2001, Chinese enterprises have accelerated their integration into the global economy and have adjusted their strategic management accordingly. Out of the need for advocating sustainable development, Chinese enterprises have been actively involved in CSR activities and have increasingly released CSR reports to reflect this [6]. As an emerging economy, however, China is a late starter in terms of CSR disclosure. The guidelines and reference criteria for CSR disclosure by Chinese enterprises are varied. In 2014, 681 out of 1526 reports (67.6\%) clarified the standards referred to in their CSR disclosure compilation processes. Among them, 456 reports referred to two or more standard frameworks. While meeting requirements imposed by the government and NGOs, these enterprises often also refer to guidelines offered by industry associations and academic institutions, both domestic and international. Of all the CSR frameworks available, three are most often adopted in CSR reporting: GRI Guidelines (referred to by 280 reports), Shanghai Stock Exchange Guidelines (referred to by 240 reports), and Chinese Academy of Social Sciences (CASS) Guidelines (referred to by 231 reports) [34]. Additionally, the Chinese Forestry Industry Association (CFIA) and the Chinese National Forest Products Industry Association (CNFPIA) released The Compilation Guidelines for CSR of China Forestry Enterprises in 2011 to regulate and guide CSR activities of forestry enterprises. From 2012 to 2016, the CFIA and CNFPIA helped to usher in the disclosure of 47 CSR reports (2011-2015) for 17 forestry companies [35], with other publicly listed forestry companies releasing their CSR reports voluntarily. This offers a unique opportunity for research to utilize recently published data.

As the largest emerging economy in the world, China is a key player in the global forest sector. That said, research on CSR disclosure in China has focused primarily on industries with a major impact on the environment and people's health like mining, metallurgicals and pharmaceuticals [36,37]. The research that does exist in the context of the Chinese forest sector [38] is problematic in that it uses small samples and a narrow conceptualization of CSR, and issues related to the factors influencing disclosure have yet to be investigated. Additional research is, thus. needed in defining the current status of CSR disclosure levels and in identifying further practical applications and development avenues for Chinese forestry companies [39-41]. 


\section{Literature Review and Hypothesis Development}

Stakeholder management theory [42,43] states that managers organize diverse information depending on multiple stakeholders. Traditionally, publicly owned companies have mainly been accountable to their shareholders, and their principal aim has been to pursue value maximization. Stakeholder management theory, however, proposes that the long-term viability of companies also needs to include the concerns of multiple stakeholders who are influential or important for the company, including customers, employees, suppliers, local communities, governments, and environmental groups $[44,45]$. Indeed, with the development of standardized reporting guidelines, such as Global Reporting Initiative, CSR disclosure in recent decades has reflected this notion by becoming more inclusive towards all stakeholders' needs [46]. All that said, this may not be the case for China. Previous studies have shown that Chinese companies tend to be more concerned with whether or not they should release CSR reports and, if so, how much information should be contained within the reports [47].

This study aims at exploring the factors influencing the CSR disclosure by Chinese forestry enterprises in light of four research hypotheses enumerated below. Hypotheses are developed in accordance with current literature on the topic, and are enumerated below.

The larger a company is, the more likely it is to draw attention from government regulatory institutions, environmental protection organizations, the media, and other social groups [7]. Larger companies, due to their higher visibility, are more likely to disclose information on their CSR to demonstrate that they are socially responsible enterprises. Research on factors influencing CSR disclosure indeed show that there is a positive correlation between the firm size and CSR disclosure levels [25,26,29-31,48-52]. For example, Li et al. [23] and Han and Hansen [26] found that larger, international forest companies are more likely to implement a broader range of CSR activities than smaller firms. We, therefore, hypothesize that:

Hypothesis 1 (H1). Corporate social responsibility disclosure is positively associated with firm size.

Management theories postulate that CSR performance is positively correlated to corporate financial performance [5]. However, there is little consensus on the correlation between CSR disclosure and profitability. Some empirical studies indicate that enterprise profit is closely correlated to levels of CSR disclosure [30,53,54], while other research (e.g., McWilliams and Siegel [55]) has shown that there is, in fact, a negative correlation or no clear correlation between CSR disclosure and profitability of a company. We, therefore, hypothesize that:

Hypothesis 2 (H2). Corporate social responsibility disclosure is positively associated with profitability.

Previous studies in other countries and regions have shown that levels of CSR disclosure are correlated to equity concentration; companies that are publicly owned are more likely to have a CSR program in place and to release information related to CSR activities. [52,56,57]. We, therefore, hypothesize that:

Hypothesis 3 (H3). Corporate social responsibility disclosure is positively associated with equity concentration.

Finally, previous research suggests that CSR activities and disclosure are dependent on the availability of financial resources within a company $[53,56]$. A company's financial position relates to the degree of financial leverage available to them [50]. We, therefore, hypothesize that:

Hypothesis 4 (H4). Corporate social responsibility disclosure is positively associated with financial leverage. 


\section{Research Design}

\subsection{Data Collection}

In order to conduct a systematic qualitative and quantitative analysis, the study sample comprises 42 publicly listed forestry companies, including, among others, well-known companies like Jilin Forest Industry Group (Changchun, China), Dare Global Co., Ltd. (Danyang, China), Fenglin Group Co., Ltd. (Nanning, China), Dehua Tubaobao Co., Ltd. (Huzhou, China). The companies in this analysis are among the first in China to release CSR disclosure reports, either voluntarily or under the auspices of the CFIA and CNFPIA. Due to a lack of consistency, the separate CSR reports were not used in this analysis; instead, the source of data was their annual reports. The companies were selected from those listed by the Shenzhen Stock Exchange [58], Shanghai Stock Exchange [59], and CNINF [60] (a website with information disclosure for listed companies in China). Thus, the data came from 209 annual reports published by these 42 companies during the period 2011-2015 (The 2011 annual report is missing for one company, Sleemon Co., Ltd.). Appendix A shows the reports for Chinese forestry companies included in this study.

\subsection{Analysis}

This paper adopts a qualitative content analysis and quantitative correlation analysis to explain factors influencing CSR disclosure levels by Chinese forestry enterprises. The analysis was conducted as follows. First, based on the literature reviewed, a working framework was created (Table 1) to assist in the categorization of CSR disclosure information. This framework categorized the disclosed CSR information into different themes, each subdivided into several dimensions in order to further analyze CSR disclosure information.

Second, the CSR reports themselves were analyzed using a content analysis. Content analysis is performed by thoroughly reading through texts and developing suitable codes that are consolidated into categories describing the text. During this process, relevant literature is used to support the interpretation of the data and the development of the codes [61-64]. Consequently, the data was coded first based on the framework (Table 1), and then with a refined category system formed by using a data-driven (abductive) approach [65]. The entire process was performed iteratively. In other words, the texts of the CSR reports were analyzed with NVivo 11.0 software, and when the category system was created, a process of manually going back and forth between the text and the framework was implemented. As a measure of reliability of content analyses, previous studies [61,63] generally refer to three characteristics: stability, reproducibility, and accuracy. To ensure reliability, we based our content analysis on two CSR disclosure guidelines released by Chinese Academy of Social Sciences and Chinese National Forestry Products Industry Association (CASS 3.0 and CNFPIA 2.0); these can be considered stable and currently valid frameworks, and the codes for this study are reproducible.

Third, the quality of CSR information disclosed in enterprises' reports was quantified by assigning scores to each specific item. This method (i.e., the application of disclosure index) has been widely used in CSR disclosure studies $[23,26]$. The scores were assigned according to the following criteria: 0 points for non-disclosure, 1 point for qualitative disclosure, and 2 points for quantitative disclosure.

Fourth, a Pearson correlation analysis using SPSS 24.0 software was run to investigate the influence of companies' firm size, ROE (return on equity, a measure of profitability), equity concentration, and leverage on CSR disclosure level. Correlation analysis was used over regression because the intent of this analysis was merely to determine association.

Table 1 shows the categorization of CSR disclosure information based on CASS 3.0 and CNFPIA 2.0, released by Chinese Academy of Social Sciences and Chinese National Forestry Products Industry Association. This framework represents currently accepted standards for Chinese forestry companies disclosing information and, consequently, serves as the foundation for this study. 
Table 1. Framework for the categorization of CSR disclosure information.

\begin{tabular}{|c|c|c|}
\hline Theme & Dimensions & Resources \\
\hline \multirow{4}{*}{ Shareholder } & Investor relation management & CASS 3.0, 2013 \\
\hline & Growth potential & CASS 3.0, 2013 \\
\hline & Profitability & CASS 3.0, 2013 \\
\hline & Safety & CASS 3.0, 2013 \\
\hline \multirow{5}{*}{ Customer } & Product quality management system & CASS 3.0, 2013; CNFPIA 2.0, 2015 \\
\hline & After-sale service system & CASS 3.0, 2013 \\
\hline & Dispute settlement mechanism & CASS 3.0, 2013 \\
\hline & Information provision of the product and services & CASS 3.0, 2013 \\
\hline & Privacy protection of customer & CASS 3.0, 2013 \\
\hline \multirow{7}{*}{ Employee } & Abidance by rule and laws & CASS 3.0, 2013 \\
\hline & Percent of contract signing & CASS 3.0, 2013 \\
\hline & Coverage of social insurance & CASS 3.0, 2013 \\
\hline & Equal employment institution & CASS 3.0, 2013 \\
\hline & Staff development training & CASS 3.0, 2013 \\
\hline & Occupational health and safe producing & CASS 3.0, 2013 \\
\hline & Staff relation management & CASS 3.0, 2013 \\
\hline \multirow{3}{*}{ Supplier } & Responsibility purchasing system & CASS 3.0, 2013 \\
\hline & Credit rating & CASS 3.0, 2013 \\
\hline & Contradict performance rate & CASS 3.0, 2013 \\
\hline \multirow{6}{*}{ Community } & The effect of enterprise operation on community & CASS 3.0, 2013 \\
\hline & Staff localization policy & CASS 3.0, 2013 \\
\hline & Localization procurement policy & CASS 3.0, 2013 \\
\hline & Donations institution and amount & CASS 3.0, 2013 \\
\hline & The policy of support for volunteer activity & CASS 3.0, 2013 \\
\hline & The data of staff volunteer activity & CASS 3.0, 2013 \\
\hline \multirow{12}{*}{ Environment protection } & Environment management system & CASS 3.0, 2013 \\
\hline & $\begin{array}{l}\text { Environmental impact assessment of new } \\
\text { investment project }\end{array}$ & CASS 3.0, 2013 \\
\hline & Forest biodiversity conservation & CNFPIA 2.0, 2015 \\
\hline & Environment protection investment & CASS 3.0, 2013; CNFPIA 2.0, 2015 \\
\hline & Sustainable forest management & CNFPIA 2.0, 2015 \\
\hline & Forest certification & CNFPIA 2.0, 2013 \\
\hline & $\begin{array}{l}\text { The quantity, kind and risk to human and } \\
\text { environment of toxic or exhaust emission }\end{array}$ & CNFPIA 2.0, 2013 \\
\hline & $\begin{array}{l}\text { Research, development, application and sale of } \\
\text { the environment production and devices }\end{array}$ & CASS 3.0, 2013; CNFPIA 2.0, 2015 \\
\hline & Energy resources conservation & CASS 3.0, 2013; CNFPIA 2.0, 2015 \\
\hline & Reduce pollution and decrease drain & CASS 3.0, 2013; CNFPIA 2.0, 2015 \\
\hline & Ecology restoration & CNFPIA 2.0, 2015 \\
\hline & Volunteer working for environment protection & CNFPIA 2.0, 2015 \\
\hline \multirow{4}{*}{ Government } & Enterprise management abided by rule & CASS 3.0, 2013 \\
\hline & Tax payment & CASS 3.0, 2013 \\
\hline & Employment security policy & CASS 3.0, 2013 \\
\hline & Employment amount over the report periods & CASS 3.0, 2013 \\
\hline
\end{tabular}

CASS: Chinese Academy of Social Sciences; CNFPIA: Chinese National Forestry Products Industry Association. 
Table 2 shows the variables considered in the correlation analysis, including firm size, return on equity (ROE), leverage, and equity concentration. Firm size was computed using the natural logarithm of total assets of the companies in order to reduce the variance. ROE is the reported return on equity of the sample companies, while leverage refers to debt ratio of the companies and equity concentration is the proportion of the firms' ownership controlled by common shareholders.

Table 2. Descriptions of variables.

\begin{tabular}{ccc}
\hline Variable & Notation & Definition \\
\hline Firm size & Size & The natural logarithm of total assets of a company at the end of a year \\
Return on equity & ROE & Net profit/net assets \\
Debt ratio & Leverage & Total debt/Total assets \\
Equity concentration & Equity & Shareholding proportion of the controlling shareholder \\
\hline
\end{tabular}

\section{Empirical Results}

\subsection{CSR Disclosure Levels}

A descriptive analysis of CSR disclosure indices (CSRDI, i.e., the qualitative summative rating of information disclosed in the reports for different items) was conducted for the 42 Chinese forestry companies in this sample based on their annual reports (Table 2). The average total score for disclosure is 37.07 , with the highest and lowest scores being 60 and 23, respectively, indicating a considerable gap between different disclosure strategies. Among the assessed dimensions, information on environment ranks highest, with a CSR disclosure index of 8.18. The shareholders (8.00) and employees (7.37) dimensions rank second and third, respectively, followed by government (5.38), customers (3.50), and community (2.58). The bottom of the list is rounded out by suppliers (2.06).

In terms of variance, the shareholders dimension has the lowest standard deviation (0.00), indicating a uniformity of information disclosed among reports. This, coupled with the mean the shareholders dimension suggest that the companies have maintained stable high levels of information disclosure on this topic. The environment dimension has the highest standard deviation (4.40), reflecting a greater variation of the information disclosed. The minimum CSDRI value for the environment dimension is 0 , revealing that some listed forestry companies have not discussed environmentally-related issues at all in their annual reports. The standard deviations of other dimensions range from 1.01 to 1.84 , suggesting little disparity among the companies with regards to information disclosure levels on customers, employees, suppliers, the community and the government dimensions. Importantly, all companies equally seem to provide very little or no information disclosure on customers, suppliers, and the community dimensions.

Figure 1 reflects the development of the CSDRI on the seven dimensions outlined in Table 3 over a period of five years (2011-2015). The data show a steadily rising tendency in the levels of information disclosed by companies, from an average total of 35.25 in 2011 to 38.34 CSDRI in 2015. For the specific dimensions, disclosure of shareholder information has been stable and comparatively high, while environmental responsibility information grew, especially in 2012, when it surpassed shareholder levels and remained at the highest level. Disclosure information on customers, communities, and suppliers are comparatively lower than the other dimensions for each of the years under study. 


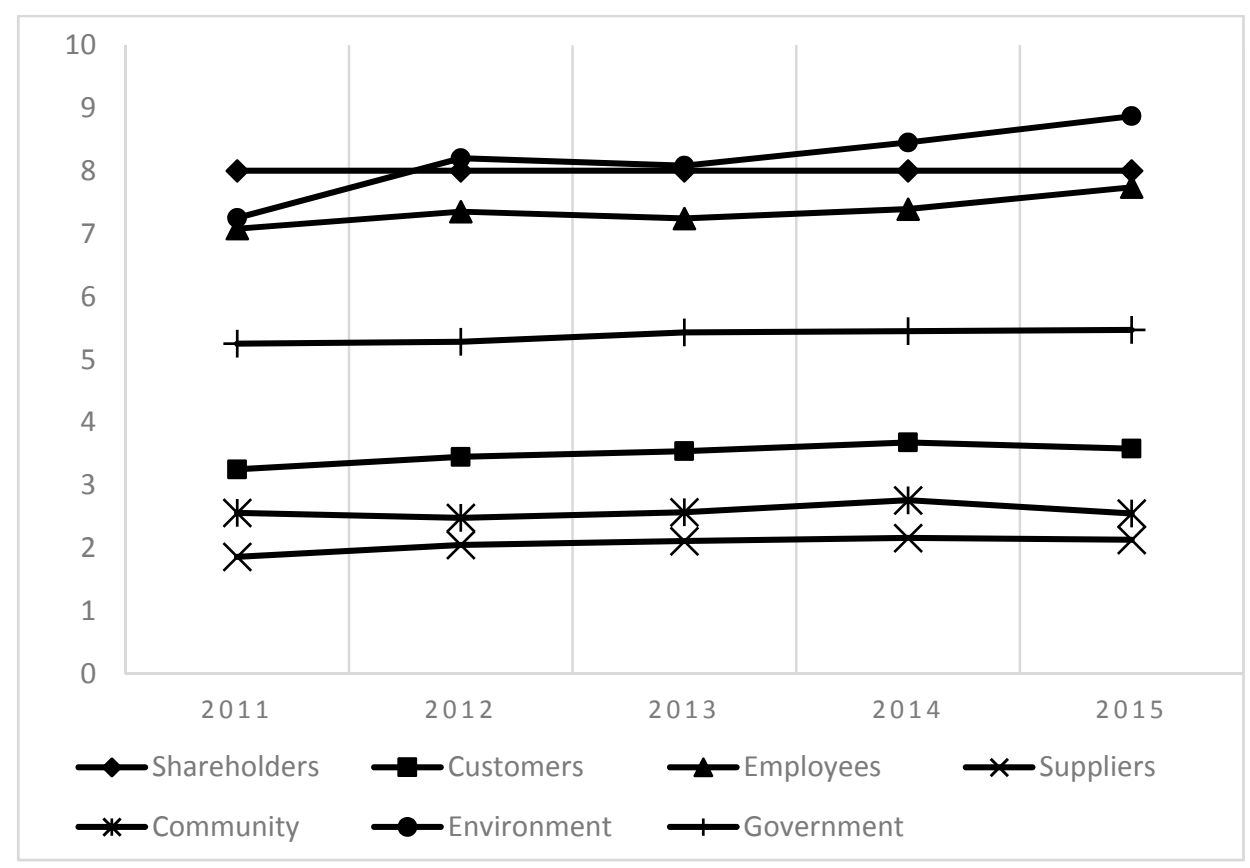

Figure 1. Five-year trends (2011-2015) of information (by dimension) disclosed by sampled forestry companies.

Table 3. Descriptive statistics of corporate social responsibility disclosure indices (CSRDI).

\begin{tabular}{cccccc}
\hline Variable & Mean & Std. Dev. & Min & Max & Median \\
\hline Total & 37.07 & 7.36 & 23 & 60 & 36 \\
Environment & 8.18 & 4.40 & 0 & 17 & 8 \\
Shareholders & 8.00 & 0.00 & 8 & 8 & 8 \\
Employees & 7.37 & 1.84 & 3 & 11 & 7 \\
Government & 5.38 & 1.01 & 3 & 7 & 5 \\
Customers & 3.50 & 1.30 & 1 & 7 & 4 \\
Community & 2.58 & 1.57 & 0 & 7 & 2 \\
Suppliers & 2.06 & 1.10 & 0 & 5 & 2 \\
\hline
\end{tabular}

\subsection{Influence of Company Characteristics on CSR Disclosure Levels}

Simple correlation analysis was run to determine the influence of firm's background characteristics on the CSR disclosure level [33] for the year 2015. Table 4 provides summary statistics computed for the variables in this analysis.

Table 4. Descriptive statistics for the variables (2015).

\begin{tabular}{ccccc}
\hline Variable & Mean & Std. Dev. & Min & Max \\
\hline Size & 9.56 & 0.44 & 8.54 & 10.89 \\
ROE & 0.12 & 0.38 & -0.13 & 2.31 \\
Leverage & 0.50 & 0.25 & 0.10 & 1.25 \\
Equity & 0.35 & 0.14 & 0.10 & 0.70 \\
\hline
\end{tabular}

In order to conduct the correlation analysis, the log of CSRDI was taken to transform non-normality of data. Table 5 shows the resulting coefficients of correlation between dependent and independent variables. The correlation coefficients indicate that CSR disclosure has positive and significant relationships with firm size and equity concentration. While the relationships with ROE and leverage are negative, they are statistically insignificant. This reveals that firm size and 
equity concentration are positively correlated with the disclosure levels among the sample companies, and that ROE and leverage had no significant impacts on disclosure levels.

Table 5. Correlation coefficients of all variables (2015).

\begin{tabular}{cccccc}
\hline & Log CSRDI & Size & ROE & Leverage & Equity \\
\hline Log CSRDI & 1.00 & & & \\
Size & $0.15^{*}$ & 1.00 & & \\
ROE & -0.01 & 0.08 & 1.00 & 1.00 & \\
Leverage & -0.12 & $0.17^{*}$ & -0.10 & $-0.23{ }^{*}$ & 1.00 \\
Equity & $0.23^{*}$ & 0.03 & 0.02 &
\end{tabular}

\section{Discussion and Conclusions}

This study analyses the disclosure development of CSR reports published by the leading listed Chinese forestry companies from 2011 to 2015. The focus of this research was on company characteristics so as to further probe the influencing factors of CSR disclosure by forestry enterprises in an emerging economy context. The results show that the CSR disclosure by Chinese forestry enterprises is still in a nascent stage, dealing primarily with economic, social, and environmental dimensions, but in varying degrees of depth. During the period of study, however, the scope and quality of CSR disclosures has expanded and improved.

Based on a descriptive analysis of summative CSR disclosure indices, the companies in this study seem to have maintained a relatively stable and comparatively high level of stakeholder information disclosure. Disclosure on environmental issues and employees is also relatively commonplace. There are, however, significant gaps in the provision of environmental information among companies, with some enterprises not disclosing any information at all. Finally, disclosure of information related to suppliers, customers, and the community is generally sparse.

These findings are in line with other international studies on CSR in the forest sector, which show that disclosure is particularly focused on environmental dimension and, to a certain degree, other economic and social issues [1,2,26] (see also a review by Ranängen and Zobel [66]). Previous studies [1,2] have pointed out that Asian forestry companies are typically more concerned with environmental performance, in particular the control of air emissions, energy efficiency, and recycling programs, compared to other parts of the world: health programs prominently featured in Africa and European companies considering CSR activities in a broader sense from both environmental and social perspectives. This study, however, shows that there is still space for improvement for Chinese forestry enterprises in terms of CSR disclosure, since they lag behind their counterparts in developed economies. That said, it should be noted that companies in emerging economies have tended to adopt disclosure frameworks appropriate to their actual conditions, which may explain global variation in the types and frequency of information that is released for the public [67]. This study also indicates, in line with previous studies [1,2], that Chinese forestry companies are increasing the amount of information that they put out on economic and social dimensions. Although the information disclosed may not be particularly significant at this juncture, it seems that CSR reporting in Chinese forestry companies is indeed moving towards a broader and more inclusive consideration of sustainability. That said, it is vital to keep in mind that this study reflects the characteristics, practices and reporting of only 42 Chinese forestry companies out of thousands. While the forestry companies in this study are among the largest and well-known forestry companies in China, signifying that they are considered business leaders, potentially, our sample could be biased towards early adopters of CSR practices and companies that are more susceptible to public criticism $[2,10]$. In other words, this analysis does not provide conclusive evidence that CSR disclosure in the Chinese forestry sector has been widely adopted. However, the adoption of CSR disclosure by these companies may catalyze others in the sector to follow suit. 
These findings are interesting in comparison to Meng et al. [7], which found that environmentallyaware enterprises in China, such as those analyzed in this study, tend to produce more thorough CSR information. Two possible reasons for this trend may be as follows. First, the policy of the Chinese government has emphasized environmental disclosure information, with the new environmental laws (2015) adding an entire chapter on this topic, including explanations and requirements for disclosure and public participation. Second, in 2015, the Chinese Forestry Industry Federation (CFIF) and the Chinese National Forestry Products Industry Association (CNFPIA) included detailed rules for the forestry industry on how to engage in corporate social responsibility [34].

Our study also reveals that the two major firm characteristics influencing levels of CSR disclosure by Chinese forestry enterprises in 2015 are firm size and equity concentration, both of which are positively correlated with the disclosure levels among the analyzed companies. The other variables under investigation, such as ROE (measured by return on equity) and leverage (measured by debt ratio), had no discernable impacts on disclosure levels. Therefore, our hypotheses $\mathrm{H} 1$ and $\mathrm{H} 4$ are confirmed, while and $\mathrm{H} 2$ and $\mathrm{H} 3$ are rejected. This is in contrast to other studies that have been conducted in other industry contexts on CSR activities of Chinese companies [68]. That said, the results of this study are in line with prior studies regarding the role of firm size on influencing CSR disclosure $[23,26,66,68]$.

Results also show no significant association between firm profitability and CSR disclosure. This correlation has often been proposed in theoretical and empirical research on CSR, but there is no consensus on whether such a correlation is characterized as positive or negative. That said, some management theories postulate that CSR disclosure is positively correlated to corporate profitability $[3,20,36]$ because better performing companies are more likely to engage with CSR, and because firms engaging with CSR are more likely to gain indirect strategic or financial benefits $[47,67]$. Other studies $[15,18,53]$ at the international level also show that there is a positive correlation between profit and CSR activities. This phenomenon was not borne out in this context of the Chinese forestry sector. A possible explanation of this could be that positive/negative correlations occur between CSR and, respectively, long/short-term profitability [67]. CSR-compliant firms may incur immediate costs, but enjoy reduced costs in the longer term. Less proactive firms, instead, may avoid initial costs, but pay a higher price over time for neglecting their CSR. Following this logic, current investments in improving CSR in the forest sector in China could bring about financial benefits for compliant firms, but they have yet to materialize.

As a shortcoming, our sample included only listed Chinese forestry companies with their annual reports being used as the data source. Consequently, the results cannot be generalized to a vast number of existing small-scale forestry enterprise in China, or even the Chinese forestry sector as a whole. Furthermore, the reporting provided by different companies in this study is very heterogeneous in style and content. Due to the small number of listed forestry companies which have released annual reports, as well as separate CSR disclosure reports, this investigation can be thought of as a case study of such companies rather than a systematic analysis. It is, in fact, possible that some CSR practices are not reflected or reported in annual reports or that others are over-reported [69]. All that said, the use of annual reports as a data source is a valid means of systematizing data collection and the framework for the information disclosed can be considered reliable (e.g., Li et al. [23], Lähtinen et al. [24]). In the future, as CSR disclosure reports in China become increasingly available, future research could attempt an even more systematic analysis, with additional information being captured through other types of documents or media, such as company websites, to create a predictive model to explore causality. A further focus for research could be to gain a better understanding of CSR practices by small and medium-sized forestry enterprises, both in China and in other emerging economies. Since the forest companies in this study are comprised of state-owned companies and privately-owned companies, it would also be interesting to shed further light on the impacts of ownership structure [70-72], especially in China. The role of political interventions on CSR disclosure, especially relevant in emerging economies like China [67], could also be investigated. 
Acknowledgments: This study was supported by the National Natural Science Foundation of China (NSFC-AF31361130342) and the Priority Academic Program Development of Jiangsu High Education Institutions (PAPD) of China. Funding by Metsäteollisuustuotteiden Vientikaupan Edistämissäätiö is also gratefully acknowledged. We are very grateful for the valuable comments and suggestions from the editor and three anonymous reviewers.

Author Contributions: Feifei Lu, Robert Kozak and Zuomin Wen conceived and designed the experiments; Feifei Lu performed the experiments; Feifei Lu, Robert Kozak, Anne Toppinen and Dalia D'Amato analyzed the data; Robert Kozak and Zuomin Wen contributed reagents/materials/analysis tools; Feifei Lu, Robert Kozak, Anne Toppinen and Dalia D'Amato wrote the paper.

Conflicts of Interest: The authors declare no conflict of interest.

\section{Appendix A}

Table A1. 1-Companies sampled in this study.

\begin{tabular}{|c|c|c|}
\hline ID & Companies (Including Listed Names) & Websites of the Companies \\
\hline 1 & Anne Co.,Ltd. (AN) & http://www.anne.com.cn/ \\
\hline 2 & Bohui Paper Co., Ltd. (BH) & http://www.bohui.com/ \\
\hline 3 & Chenming Paper Group Co., Ltd. (CM) & http://www.chenmingpaper.com/ \\
\hline 4 & Dare Global Co., Ltd. (DR) & http://www.dareglobal.com.cn/ \\
\hline 5 & Dehua Tubaobao Co., Ltd. (TB) & http:/ /www.tubaobao.com/ \\
\hline 6 & Der Group Co., Ltd. (DER) & http://www.der.com.cn/ \\
\hline 7 & Fenglin Group Co., Ltd. (FL) & http://www.fenglingroup.com/ \\
\hline 8 & Fujian Jinsen Forestry Co., Ltd. (JS) & http://www.jinsenforestry.com/ \\
\hline 9 & Fujian Qingshan Paper Industry Co., Ltd. (QS) & http://www.qingshanpaper.com/ \\
\hline 10 & Fujian Yong'an Forestry Co.,Ltd. (YL) & http://www.yonglin.com/ \\
\hline 11 & Guangdong Guanhao High-Tech Co., Ltd. (GH) & http://www.guanhao.com/cn/ \\
\hline 12 & Guangdong Weihua Co.,Ltd. (WH) & http://erikou.cn.globalimporter.net/ \\
\hline 13 & Guangxi Guitang(Group) Co., Ltd. (GT) & http://www.guitang.com/ \\
\hline 14 & Huatai Securities Co., Ltd. (HT) & http://www.htsc.com.cn/ \\
\hline 15 & Huaxin Pakaging Co., Ltd. (HX) & http://www.fshxp.com/ \\
\hline 16 & Hnec YingeTouzi Co., Ltd. (YG) & http://www.yinge.com.cn/ \\
\hline 17 & Jiangmen Sugarcane Chemical Factory(Group)Co., Ltd. (GH) & http://www.gdganhua.com/ \\
\hline 18 & Jincheng Paper Co.,Ltd. (JC) & http://pjzbk.cn.gongchang.com/ \\
\hline 19 & Jilin Forest Industry Group (FI) & http://www.jlsgjt.com/index \\
\hline 20 & Markor Real Estate Co., Ltd. (MK) & http://www.meikezhidi.com/ \\
\hline 21 & Meiyingsen Group Co.,Ltd. (MYS) & http://www.szmys.com/ \\
\hline 22 & Minfeng Special Paper Co., Ltd. (MF) & http://www.minfenggroup.com/ \\
\hline 23 & Mudanjiang Hengfeng Paper Co., Ltd. (HF) & http://www.hengfengpaper.com/ \\
\hline 24 & Mcc Meili Paper Industry Co., Ltd. ( ML) & http://www.china-meili.com/ \\
\hline 25 & Qifeng New Material Co., Ltd. (QF) & http://www.qifeng.cn/ \\
\hline 26 & Shandong Sun Paper Co.,Ltd. (SP) & http://www.sunpapergroup.com/ \\
\hline 27 & Shanghai Lvxo Tech. Co., Ltd. (LX) & http://www.luxinevotech.com/ \\
\hline 28 & Shanying Paper Co., Ltd. (SY) & http://www.shanyingpaper.com/ \\
\hline 29 & Shengda Forestry Co.,Ltd. (SD) & http://www.365sdf.com/ \\
\hline 30 & Sichuan Guodong Construction Group Co., Ltd. (GD) & http://www.guodong.cn/ \\
\hline 31 & Sleemon Co., Ltd. (SM) & http://www.chinabed.com/ \\
\hline 32 & Sophia Household Co., Ltd. (SPH) & http://www.sogal.com.cn/ \\
\hline 33 & Xiamen Hexing Packaging Printing Co., Ltd. (HX) & http://www.hxpp.com.cn/ \\
\hline 34 & Yibin Paper Industry Co., Ltd. (YB) & http://www.yb-zy.com/ \\
\hline 35 & Yueyang Forest \&Paper Co.,Ltd. (YFP) & http://www.yypaper.com/ \\
\hline 36 & Yunnan Jinggu Forestry Co., Ltd. (JG) & http://www.jgly.cn/ \\
\hline 37 & Yuntou Ecology Co., Ltd. (YT) & http://www.yt-eco.com/ \\
\hline 38 & Zhejian Jingxing Paper Co.,Ltd. (JX) & http://zjjxzy.cn.china.cn/ \\
\hline 39 & Zhejiang Kan Special Material Co., Ltd. (KAN) & http://www.zjkan.com/ \\
\hline 40 & Zhejiang Yongqiang Group Co., Ltd. (YQ) & http://www.yongjiangchina.com/ \\
\hline 41 & Zhongfu Pingtan Development Co., Ltd. (PTD) & http://www.000592.com/ \\
\hline 42 & Zhongshun Jierou Group Co., Ltd. (ZS) & http://www.zhongshungroup.com/lxfs.aspx \\
\hline
\end{tabular}


Table A2. 2-Disclosure indices of each theme from 2011-2015.

\begin{tabular}{|c|c|c|c|c|c|c|c|c|c|}
\hline \multirow[t]{2}{*}{ Theme } & \multirow{2}{*}{$\begin{array}{l}\text { Dimensions } \\
\text { Investor relation management }\end{array}$} & \multicolumn{5}{|c|}{ Disclosure Indices (2011-2015) } & \multirow{2}{*}{$\begin{array}{c}\text { Mean } \\
2.00\end{array}$} & \multirow{2}{*}{$\begin{array}{c}\text { Min } \\
2.00\end{array}$} & \multirow{2}{*}{$\begin{array}{l}\text { Max } \\
2.00\end{array}$} \\
\hline & & 2.00 & 2.00 & 2.00 & 2.00 & 2.00 & & & \\
\hline \multirow{3}{*}{ Shareholder } & Growth potential & 2.00 & 2.00 & 2.00 & 2.00 & 2.00 & 2.00 & 2.00 & 2.00 \\
\hline & Profitability & 2.00 & 2.00 & 2.00 & 2.00 & 2.00 & 2.00 & 2.00 & 2.00 \\
\hline & Safety & 2.00 & 2.00 & 2.00 & 2.00 & 2.00 & 2.00 & 2.00 & 2.00 \\
\hline \multirow{5}{*}{ Customer } & Product quality management system & 0.78 & 0.85 & 0.81 & 0.92 & 0.92 & 0.86 & 0.00 & 2.00 \\
\hline & After-sale service system & 0.69 & 0.73 & 0.78 & 0.76 & 0.71 & 0.74 & 0.00 & 2.00 \\
\hline & Dispute settlement mechanism & 0.19 & 0.25 & 0.30 & 0.29 & 0.32 & 0.27 & 0.00 & 2.00 \\
\hline & Information provision of the product and services & 1.56 & 1.58 & 1.59 & 1.63 & 1.58 & 1.59 & 0.00 & 2.00 \\
\hline & Privacy protection of customer & 0.03 & 0.05 & 0.05 & 0.08 & 0.05 & 0.05 & 0.00 & 1.00 \\
\hline \multirow{7}{*}{ Employee } & Abidance by rule and laws & 0.78 & 0.88 & 0.84 & 0.84 & 0.87 & 0.84 & 0.00 & 2.00 \\
\hline & Percent of contract signing & 0.44 & 0.53 & 0.46 & 0.45 & 0.45 & 0.47 & 0.00 & 2.00 \\
\hline & Coverage of social insurance & 1.83 & 1.85 & 1.86 & 1.87 & 1.87 & 1.86 & 0.00 & 2.00 \\
\hline & Equal employment institution & 0.17 & 0.20 & 0.19 & 0.18 & 0.21 & 0.19 & 0.00 & 1.00 \\
\hline & Staff development training & 1.22 & 1.30 & 1.27 & 1.34 & 1.45 & 1.32 & 0.00 & 2.00 \\
\hline & Occupational health and safe producing & 0.72 & 0.75 & 0.81 & 0.82 & 0.97 & 0.81 & 0.00 & 2.00 \\
\hline & Staff relation management & 1.92 & 1.85 & 1.81 & 1.89 & 1.92 & 1.88 & 0.00 & 2.00 \\
\hline \multirow{3}{*}{ Supplier } & Responsibility purchasing system & 1.03 & 1.03 & 1.05 & 1.00 & 0.97 & 1.02 & 0.00 & 2.00 \\
\hline & Credit rating & 0.47 & 0.68 & 0.68 & 0.82 & 0.84 & 0.70 & 0.00 & 2.00 \\
\hline & Contradict performance rate & 0.36 & 0.35 & 0.38 & 0.34 & 0.32 & 0.35 & 0.00 & 1.00 \\
\hline \multirow{5}{*}{ Community } & The effect of enterprise operation on community & 0.19 & 0.30 & 0.30 & 0.37 & 0.34 & 0.30 & 0.00 & 1.00 \\
\hline & Staff localization policy & 0.03 & 0.10 & 0.03 & 0.11 & 0.05 & 0.06 & 0.00 & 1.00 \\
\hline & Localization procurement policy & 0.11 & 0.15 & 0.19 & 0.18 & 0.18 & 0.16 & 0.00 & 1.00 \\
\hline & Donations institution and amount & 1.89 & 1.70 & 1.73 & 1.79 & 1.71 & 1.76 & 0.00 & 2.00 \\
\hline & The policy of support for volunteer activity & 0.17 & 0.13 & 0.19 & 0.18 & 0.16 & 0.16 & 0.00 & 2.00 \\
\hline
\end{tabular}


Table A2. Cont.

\begin{tabular}{|c|c|c|c|c|c|c|c|c|c|}
\hline \multirow[t]{2}{*}{ Theme } & \multirow{2}{*}{$\begin{array}{l}\text { Dimensions } \\
\text { The data of staff volunteer activity }\end{array}$} & \multicolumn{5}{|c|}{ Disclosure Indices (2011-2015) } & \multirow{2}{*}{$\begin{array}{c}\text { Mean } \\
0.13\end{array}$} & \multirow{2}{*}{$\begin{array}{l}\text { Min } \\
0.00\end{array}$} & \multirow{2}{*}{$\begin{array}{l}\text { Max } \\
2.00\end{array}$} \\
\hline & & 0.17 & 0.10 & 0.14 & 0.13 & 0.11 & & & \\
\hline \multirow{12}{*}{$\begin{array}{l}\text { Environment } \\
\text { protection }\end{array}$} & Environment management system & 0.50 & 0.88 & 0.86 & 0.89 & 1.03 & 0.84 & 0.00 & 2.00 \\
\hline & Environmental impact assessment of new investment project & 0.39 & 0.40 & 0.43 & 0.42 & 0.42 & 0.41 & 0.00 & 2.00 \\
\hline & Forest biodiversity conservation & 0.00 & 0.08 & 0.00 & 0.08 & 0.03 & 0.04 & 0.00 & 1.00 \\
\hline & Environment protection investment & 1.28 & 1.28 & 1.27 & 1.29 & 1.34 & 1.29 & 0.00 & 2.00 \\
\hline & Sustainable forest management & 0.28 & 0.33 & 0.32 & 0.37 & 0.39 & 0.34 & 0.00 & 2.00 \\
\hline & Forest certification & 0.08 & 0.28 & 0.19 & 0.29 & 0.29 & 0.23 & 0.00 & 2.00 \\
\hline & $\begin{array}{l}\text { The quantity, kind and risk to human and environment of } \\
\text { toxic or exhaust emission }\end{array}$ & 0.72 & 0.80 & 0.84 & 0.87 & 0.92 & 0.83 & 0.00 & 2.00 \\
\hline & $\begin{array}{l}\text { Research, development, application and sale of the } \\
\text { environment production and devices }\end{array}$ & 1.06 & 1.13 & 1.16 & 1.08 & 1.08 & 1.10 & 0.00 & 2.00 \\
\hline & Energy resources conservation & 1.14 & 1.20 & 1.16 & 1.24 & 1.29 & 1.21 & 0.00 & 2.00 \\
\hline & Reduce pollution and decrease drain & 1.08 & 1.08 & 1.05 & 1.08 & 1.16 & 1.09 & 0.00 & 2.00 \\
\hline & Ecology restoration & 0.33 & 0.30 & 0.30 & 0.37 & 0.45 & 0.35 & 0.00 & 2.00 \\
\hline & Volunteer working for environment protection & 0.39 & 0.48 & 0.49 & 0.47 & 0.47 & 0.46 & 0.00 & 2.00 \\
\hline \multirow{4}{*}{ Government } & Enterprise management abided by rule & 1.00 & 1.00 & 1.00 & 1.00 & 1.00 & 1.00 & 1.00 & 1.00 \\
\hline & Tax payment & 2.00 & 2.00 & 2.00 & 2.00 & 2.00 & 2.00 & 2.00 & 2.00 \\
\hline & Employment security policy & 0.53 & 0.53 & 0.65 & 0.66 & 0.68 & 0.61 & 0.00 & 2.00 \\
\hline & Employment amount over the report periods & 1.72 & 1.75 & 1.78 & 1.79 & 1.79 & 1.77 & 0.00 & 2.00 \\
\hline
\end{tabular}

The disclosure index of each dimension is the mean of the sample companies of each year from 2011-2015. 


\section{References}

1. Vidal, N.G.; Kozak, R.A. Corporate responsibility practices in the forestry sector: Definitions and the role of context. J. Corp. Citizsh. 2008, 31, 59-75. [CrossRef]

2. Vidal, N.G.; Kozak, R.A. The recent evolution of corporate responsibility practices in the Forestry Sector. Int. For. Rev. 2008, 10, 1-13. [CrossRef]

3. Cho, C.H.; Patten, D.M. The role of environmental disclosures as tools of legitimacy: A research note. Account. Organ. Soc. 2007, 32, 639-647. [CrossRef]

4. Uyar, A. Evolution of Corporate Reporting and Emerging Trends. J. Corp. Account. Financ. 2016, 27, 27-30. [CrossRef]

5. Brown, H.S.; De Jong, M.; Lessidrenska, T. The rise of the Global Reporting Initiative: A case of institutional entrepreneurship. Environ. Politics 2009, 18, 182-200. [CrossRef]

6. Labuschagne, C.; Brent, A.C.; Van Erck, R.P.G. Assessing the sustainability performances of industries. J. Clean. Prod. 2005, 13, 373-385. [CrossRef]

7. Meng, X.H.; Zeng, S.X.; Tam, C.M. From voluntarism to regulation: A study on ownership, economic performance and corporate environmental information disclosure in China. J. Bus. Ethics 2013, 116, 217-232. [CrossRef]

8. Cohen, D.; Mathey, A.H.; Biggs, J.; Boyland, M. Corporate Social Responsibility. In The Global Forest Sector: Changes, Practices and Prospects; Taylor and Francis Group: Didcot, UK, 2014; pp. 353-376.

9. Hansen, E.; Juslin, H. Strategic Marketing in the Global Forest Industries; Authors Academic Press: Corvallis, OR, USA, 2011.

10. Panwar, R.; Hansen, E.; Kozak, R. (Eds.) Forests, Business and Sustainability; Routledge: New York, NY, USA, 2016.

11. Toppinen, A.; Korhonen-Kurki, K. Global reporting initiative and social impact in managing corporate responsibility: A case study of three multinationals in the forest industry. Bus. Ethics Eur. Rev. 2013, 22, 202-217. [CrossRef]

12. Toppinen, A.; Lähtinen, K.; Holopainen, J. On Corporate Responsibility. In Forests, Business and Sustainability; Panwar, R., Hansen, E., Kozak, R., Eds.; Routledge: New York, NY, USA, 2016; pp. 70-90.

13. Korhonen, J.; Zhang, Y.; Toppinen, A. Examining vertical integration in the global forest sector. For. Policy Econ. 2016, 70, 39-46. [CrossRef]

14. Panwar, R.; Hansen, E.; Kozak, R. Evaluating social and environmental issues by integrating the legitimacy gap with expectational gaps: An empirical assessment of the forest industry. Bus. Soc. 2014, 53, 853-875. [CrossRef]

15. Panwar, R.; Paul, K.; Nybakk, E.; Hansen, E.; Thompson, D. The legitimacy of CSR actions of publicly traded companies versus family-owned companies. J. Bus. Ethics 2014, 125, 481-496. [CrossRef]

16. Pätäri, S.; Tuppura, A.; Toppinen, A.; Korhonen, J. Global sustainability megaforces in shaping the future of the European pulp and paper industry towards a bioeconomy. For. Policy Econ. 2016, 66, 38-46. [CrossRef]

17. Toppinen, A.; Zhang, Y.; Hansen, E.; Korhonen-Kurki, K.; Li, N. Role of corporate responsibility: Insights from three forest-industry multinationals investing in China. In From Global Pressures to Local Responses; IUFRO World Series; Katila, P., Galloway, G., de Jong, W., Pacheco, P., Mery, G., Eds.; Taylor and Francis Group: Didcot, UK, 2014; Volume 32, pp. 217-228.

18. Tuppura, A.; Toppinen, A.; Jantunen, A. Proactiveness and corporate social performance in the global forest industry. Int. For. Rev. 2013, 15, 112-121. [CrossRef]

19. Mikkilä, M.; Toppinen, A. Corporate responsibility reporting by large pulp and paper companies. For. Policy Econ. 2008, 10, 500-506. [CrossRef]

20. Abeysekera, A.; Lu, Y.J. Social and Environmental Disclosure by Chinese Firms; Routledge: London, UK; Taylor \& Francis Group: New York, NY, USA, 2014.

21. Kim, N.; Moon, J.J.; Yin, H. Environmental pressure and the performance of foreign firms in an emerging economy. J. Bus. Ethics 2015, 137, 475-490. [CrossRef]

22. D'Amato, D.; Li, N.; Rekola, M.; Toppinen, A.; Lu, F.F. Linking forest ecosystem services to corporate sustainability disclosure: A conceptual analysis. Ecosyst. Serv. 2015, 14, 170-178. [CrossRef]

23. Li, N.; Toppinen, A.; Tuppura, A.; Puumalainen, K.; Hujala, M. Determinants of sustainability disclosure in the global forest industry. Electr. J. Bus. Ethics. Organ. Stud. 2011, 16, 33-40. 
24. Lähtinen, K.; Toppinen, A.; Mikkilä, M.; Toivio, M.; Suur-Uski, O. Corporate responsibility reporting in promoting social license to operate in forestry and sawmilling industries. Forestry 2016, 89, 2-17. [CrossRef]

25. Toppinen, A.; Li, N.; Tuppura, A.; Xiong, Y. Corporate responsibility andstrategic groups in the forest- based industry: Exploratory analysis based on the global reporting initiative (GRI) framework. Corp. Soc. Responsib. Environ. Manag. 2012, 19, 191-205. [CrossRef]

26. Han, X.O.; Hansen, E. Corporate social responsibility implementation in the global forest sector. J. Corp. Citizsh. 2012, 47, 101-118. [CrossRef]

27. Liu, X.B.; Yu, Q.Q.; Fujitsuka, T.; Liu, B.B.; Bi, J.; Shishime, T. Functional mechanisms of mandatory corporate environmental disclosure: An empirical study in China. J. Clean. Prod. 2010, 18, 823-832. [CrossRef]

28. Xu, X.D.; Zeng, S.X.; Tam, C.M. Stock market's reaction to disclosure of environmental violation: Evidence from China. J. Bus. Ethics 2012, 107, 227-237. [CrossRef]

29. Adams, C.A.; Hill, W.Y.; Roberts, C.B. Corporate social reporting practices in Western Europe: Legitimating corporate behavior. Br. Account. Rev. 1998, 30, 1-21. [CrossRef]

30. Ho, S.S.M.; Wong, K.S. A study of corporate disclosure practices and effectiveness in Hong Kong. J. Intern. Financ. Manag. Account. 2001, 12, 75-102. [CrossRef]

31. Barako, D.G.; Hancock, P.; Izan, H.Y. Factors influencing voluntary corporate disclosure by Kenyan companies. Corp. Gov. Int. Rev. 2006, 14, 107-125. [CrossRef]

32. Hossain, M.; Reaz, M. The determinants and characteristics of voluntary disclosure by Indian banking companies. Corp. Soc. Responsib. Environ. Manag. 2007, 14, 274-288. [CrossRef]

33. Reverte, C. Determinants of corporate social responsibility disclosure ratings by Spanish listed firms. J. Bus. Ethics 2009, 88, 351-366. [CrossRef]

34. China National Forest Products Industry Association (CNFPIA). The White Paper of Corporate Social Responsibility (CSR) in Forestry Enterprises of China; CNFPIA: Beijing, China, 2015.

35. China National Forest Products Industry Association (CNFPIA). Available online: http://www.cnfpia.org/ index.html (accessed on 22 August 2016).

36. Ding, L.H. Factoring influencing on corporate social responsibility. Accoun. Commun. 2016, 3, 59-61.

37. He, L.M.; Ma, J.Y. Research on factors influencing on environmental performance information disclosure of pharmaceutical enterprises. Econ. Manag. 2011, 33, 26-31.

38. Sui, S.; Zhang, W.M. Framework of social responsibility of forestry enterprises. J. BFU (Soc. Sci.) 2012, 11, 108-113.

39. Yin, Z.H.; Song, W.M.; Tian, M.H. Thoughts on corporate social responsibility of forestry enterprises in China. World For. Res. 2011, 24, 71-74.

40. Jiang, D.Q.; Tian, Z.W. Study on Social Responsibility about Forestry Enterprises in China. For. Econ. 2011, 8, 75-78.

41. Wang, L.; Juslin, H. Corporate social responsibility in the Chinese forest industry: Understanding multiple stakeholder perceptions. Corp. Soc. Responsib. Environ. Manag. 2013, 20, 129-145. [CrossRef]

42. Freeman, E. Strategic Management: A Stakeholder Approach; Pitman Publishing: Boston, MA, USA, 1984.

43. Jamali, D. A stakeholder approach to corporate social responsibility: A fresh perspective into theory and practice. J. Bus. Ethics 2008, 82, 213-231. [CrossRef]

44. Simmons, J. Managing in the post-managerialist era: Towards socially responsible corporate governance. Manag.Decis. 2004, 42, 601-611. [CrossRef]

45. Brickson, S. Organizational identity orientation: The genesis of the role of the firm and distinct forms of social value. Acad. Manag. Rev. 2007, 32, 864-888. [CrossRef]

46. Gray, R.; Bebbington, J. Corporate sustainability, accountability and the pursuit of the impossible dream. In Handbook of Sustainable Development; Atkinson, G.S., Dietz, S., Neumeyer, E., Eds.; Cheltenham Edward Elgar: Cheltenham, UK, 2007; pp. 376-394.

47. Li, Q.; Luo, W.; Wang, Y.; Wu, L. Firm performance, corporate ownership, and corporate social responsibility disclosure in China. J. Bus. Ethics 2013. [CrossRef]

48. Wallace, R.S.O.; Naser, K.; Mora, A. The relationship between the comprehensiveness of corporate annual reports and firm specific characteristics in Spain. Account. Bus. Res. 1994, 25, 41-53. [CrossRef]

49. Watson, A.; Shrives, P.; Marston, C. Voluntary disclosure of accounting ratios in the UK. Br. Account. Rev. 2002, 34, 289-313. [CrossRef] 
50. Branco, M.C.; Rodrigues, L.L. Factors influencing social responsibility disclosure by Portuguese companies. J. Bus. Ethics 2008, 83, 685-701. [CrossRef]

51. Preuss, L.; Perschke, J. Slipstreaming the larger boats: Social responsibility in medium-sized businesses. J. Bus. Ethics 2010, 92, 531-551. [CrossRef]

52. Rouf, A. The corporate social responsibility disclosure: A study of listed companies in Bangladesh. Bus. Econ. Res. J. 2011, 2, 19-32.

53. Roberts, R.W. Determinants of corporate social responsibility disclosure: An application of stake- holder theory. Account. Organ. Soc. 1992, 17, 595-612. [CrossRef]

54. Li, N.; Puumalainen, K.; Toppinen, A. Managerial perceptions of corporate social and financial performance in the global forest industry. Int. For. Rev. 2014, 16, 319-338. [CrossRef]

55. McWilliams, A.; Siegel, D. Corporate social responsibility and financial performance: Correlation or misspecification? Strat. Manag. J. 2000, 2, 33-52.

56. Nazli, A.M.G. Ownership structure and corporate social responsibility disclosure: Some Malaysian evidence. Corp. Gov. Int. J. Bus. Soc. 2007, 7, 251-266.

57. Sufian, A. Ownership structure and corporate social responsibility disclosure in Bangladesh. Int. J. Econ. Financ. Issues 2013, 3, 901-909.

58. Shenzhen Stock Exchange. 2016. Available online: www.sse.com.cn (accessed on 26 August 2016).

59. Shanghai Stock Exchange. 2016. Available online: www.szse.cn (accessed on 26 August 2016).

60. CNINF. 2016. Available online: www.cninfo.com.cn (accessed on 26 August 2016).

61. Krippendorf, K. Content Analysis: An Introduction to Its Methodology, 3rd ed.; Sage Publications: Thousand Oaks, CA, USA, 2013.

62. Gioia, D.A.; Corley, K.G.; Hamilton, A.L. Seeking qualitative rigor in inductive research: Notes on the Gioia methodology. Organ. Res. Methods 2013, 16, 15-31. [CrossRef]

63. Vourvachis, P.; Woodward, T. Content analysis in social and environmental reporting research: Trends and challenges. J. Appl. Account. Res. 2015, 16, 166-195. [CrossRef]

64. Neuendorf, K.A. The Content Analysis Guidebook; SAGE Publication, Inc.: Thousand Oaks, CA, USA, 2016.

65. Flick, U. An Introduction to Qualitative Research; SAGE Publications Ltd.: Thousand Oaks, CA, USA, 2009.

66. Ranängen, H.; Zobel, T. Revisiting the 'how' of corporate social responsibility in extractive industries and forestry. J. Clean. Prod. 2014, 84, 299-312. [CrossRef]

67. Li, W.J.; Zhang, R. Corporate social responsibility, ownership structure, and political interference: Evidence from China. J. Bus. Ethics 2010, 96, 631-645.

68. Li, Y.H.; Foo, C.K. Managing CSR inside China. In Diversity of Managerial Perspectives from inside China; Foo, C.K., Ed.; Springer: Berlin, Germany, 2016.

69. Aras, G.; Crowther, D. Corporate sustainability reporting: A study in disingenuity? J. Bus. Ethics 2009. [CrossRef]

70. Ntim, C.G.; Soobaroyen, T. Black Economic Empowerment Disclosures by South African Listed Corporations: The Influence of Ownership and Board Characteristics. J. Bus. Ethics 2013, 116, 121-138. [CrossRef]

71. Al-Bassam, W.M.; Ntim, C.G.; Opong, K.K.; Downs, Y. Corporate Boards and Ownership Structure as Antecedents of Corporate Governance Disclosure in Saudi Arabian Publicly Listed Corporations. Bus. Soc. 2015. [CrossRef]

72. Ntim, C.G.; Soobaroyen, T.; Broad, M.J. Governance structures, voluntarydisclosures and public accountability. The case of UK higher education institutions. Account. Audit. Account. J. 2017, 30, 65-118. [CrossRef]

(C) 2017 by the authors. Licensee MDPI, Basel, Switzerland. This article is an open access article distributed under the terms and conditions of the Creative Commons Attribution (CC BY) license (http://creativecommons.org/licenses/by/4.0/). 